MISE AU POINT/ IN口DEPTH REVIEW

\title{
AN UPDATE ON THALASSEMIA INTERMEDIA
}

http://www.lebanesemedicaljournal.org/articles/61-3/review1.pdf

\author{
Joseph E. MAAKARON ${ }^{1}$, Maria Domenica CAPPELLINI ${ }^{2}$, Ali T. TAHER ${ }^{1}$
}

Maakaron JE, Cappellini MD, Taher AT. An update on thalassemia intermedia. J Med Liban 2013 ; 61 (3) : 175-182.

ABSTRACT : Thalassemia intermedia is a genetically diverse group of diseases that is the result of an imbalance in the production of the alpha and beta chains with ensuing chronic hemolysis, ineffective erythropoiesis, and iron overload. Resulting complications include bone changes, hypercoagulability, and endorgan damage due to iron overload. This decade has witnessed major breakthroughs in the management of thalassemia. In this article, we examine these novelties in therapy including iron chelation therapy, stem cell transplant, and gene therapy. Iron chelation therapy has been revolutionized with the advent of deferasirox, a once-daily oral iron chelator, that has been shown to be safe and efficacious. Gene therapy was also at the core of this revolution with the discovery of novel gene elements and viral vectors allowing for better control and improved outcomes.

Keywords : thalassemia, thalassemia intermedia, iron chelation, ineffective erythropoiesis, hematopoietic stem cell transplant, iron overload, hemoglobinopathy, gene therapy, Jak2 inhibitor

\section{HISTORICAL OVERVIEW}

Thalassemia was first described by two American pediatricians, Thomas B. Cooley and Pearl Lee [1]. They reported a series of five children with severe anemia, growth retardation, and peculiar bone abnormalities [2-3]. It was first called "erythroblastic anemia." The term thalassemia was later coined by George Whipple [4]. Thalassemia roughly translates to "anemia of the sea," signifying the fact that most patients were of Mediterranean origin. Insight into the pathophysiology came when Sir David Weatherall and Dr. John Clegg and their colleagues were able to isolate and separate the thalassemiaglobin chain. They deduced that the culprit was an imbalance in chain

${ }^{1}$ Department of Internal Medicine, Division of Hematology and Oncology, American University of Beirut Medical Center, Beirut, Lebanon. ${ }^{2}$ Department of Internal Medicine, Fondazione IRCCS "CaGranda", Ospedale Maggiore Policlinico, University of Milan, Milan, Italy

Correspondence: A. T. Taher, MD. Hematology-Oncology Division. Department of Internal Medicine. American University of Beirut Medical Center. P.O. Box: 11-0236 Riad El-Solh. 11072020 Beirut. Lebanon.

e-mail: ataher@aub.edu.lb
Maakaron JE, Cappellini MD, Taher AT. Une mise à jour sur la thalassémie intermédiaire. J Med Liban 2013 ; 61 (3) : 175-182.

RÉSUMÉ : La thalassémie intermédiaire englobe un groupe de maladies diverses résultant d'un déséquilibre entre la production des chaînes alfa et bêta qui aboutit à une hémolyse chronique, une érythropoïèse inefficace et une surcharge en fer. Les complications engendrées par cette maladie sont un changement dans la constitution des os, un état d'hypercoagulabilité, et des organes majeurs endommagés suite au surplus de fer. La dernière décennie a vu d'importantes avancées dans le traitment de la thalassémie. Sont examinées ici les toutes dernières thérapeutiques : la chélation du fer, la greffe de cellules souches et la thérapie génétique. L'introduction de deferasirox, un chélateur du fer administré une fois par jour par voie orale, a révolutionné la chélation du fer et s'est imposé comme étant un médicament sûr et efficace. La thérapie génétique a aussi été une innovation charnière dans les nouveaux traitements, surtout avec la découverte récente d'éléments génétiques et vecteurs viraux qui permettent un meilleur contrôle et améliorent les résultats.

Mots-clés: thalassémie, thalassémie intermédiaire, chélation du fer, érythropoïèse inefficace, greffe de cellules souches, surcharge en fer, hémoglobinopathie, thérapie génétique, inhibiteur de Jak2

synthesis [5]. Their theory still holds till now. Betathalassemia is a defect in the synthesis of the beta chain of the hemoglobin leading to imbalance in the $\alpha / \beta$ ratio in the red blood cells (RBC), ineffective erythropoiesis, and a spectrum of anemia [6]. Thalassemia major (TM) is when the synthesis defect is profound leading to severe anemia requiring blood transfusion within the first year of life. On the other hand of the spectrum, we have thalassemia minor (Tm) which is completely asymptomatic and only manifests as a mild hypochromic, microcytic anemia. Sturgeon described a third group of patients with manifestations that are too severe to be called minor and too mild to be called major. He suggested the term thalassemia intermedia for this population [7].

\section{GENETICALLY SPEAKING}

Thalassemia intermedia (TI) is in itself a spectrum of diseases. Mildly affected patients remain completely asymptomatic till adult life, with their only abnormality being mild anemia with hemoglobin $(\mathrm{Hb})$ levels maintained between 7-10 g/dl. More severely affected patients 
present younger, between 2 and 6 years of age, and require transfusions for normal and sustained growth [8]. While $\mathrm{Tm}$ is the result of disruption of one of the beta chains and TM is the result of disruption of both of these chains, TI has a myriad of genotypes associated with it and is still a clinical diagnosis. It usually results from a homozygous or a compound heterozygous mutation [9]. Rarely, it can also result from only one chain being affected, making it dominantly inherited [10]. TI is milder than TM because of several reasons. It can be due to inheritance of a mild mutation, resulting in subnormal synthesis of beta chains instead of complete absence. It can also be due to coinheritance of determinants that increase gamma-chain production to stabilize the excess alpha chains. Coinheritance of alpha-thalassemia will also lead to a TI phenotype since less alpha chains will remain unpaired. One can inherit triplicated or quadruplicated alpha genotype associated with beta heterozygosity and manifest a TI phenotype. Polymorphisms that alter bone, iron, and bilirubin metabolism can also affect the clinical expression of the disease. These are called tertiary modifiers. Environmental and socioeconomic factors also play a role in the presentation. With so many factors in play (Table I), it is no surprise that TI has such a wide range of clinical presentations.

Some studies have aimed at stratifying TI patients by severity, and attempted to predict a genotype-phenotype relationship to better tailor the treatment guidelines [1112]. Phadke and Agarwal devised a score based on the clinical presentation to classify patients. The score was composed of relevant clinical characteristics such as age at presentation, severity of the anemia, extent of growth retardation and bone marrow hyperplasia, blood transfusion requirements, and need for splenectomy [13]. This score might prove to be of great value in classifying patients and relating genotype to phenotype when developing treatment guidelines; however, more studies will have the final say in this. The diagnosis of TI remains a clinical one and can be very challenging at both ends of the spectrum.

\section{PATHOPHYSIOLOGY}

The alpha and beta chains in a normal red blood cell (RBC) should precisely match each other. In beta-thalassemia, underproduction of the beta chains causes excess, unstable alpha chains to deposit in the RBC, thus produc- ing oxidative damage to the membrane and subsequent lysis of the cells - this is ineffective erythropoiesis [14]. This causes the bone marrow to hypertrophy, resulting in characteristic deformities of the skull and face. Cortical thinning and pathological fractures are also common [15]. The primary determinant of the anemia is the degree of ineffective erythropoiesis rather than the degree of hemolysis, which only plays a secondary role [16]. Instead, hemolysis is linked to the hypercoagulable state in TI [17] leading to silent infarcts [18] and pulmonary hypertension. The anemia and the ineffective erythropoiesis increase intestinal iron absorption leading to iron overload, which causes heart failure, endocrine abnormalities and others (Figure 1).

\section{COMPLICATIONS}

The combination of ineffective erythropoiesis, chronic hemolysis and iron overload eventually culminate in the complications we see in TI. Our first attempt at understanding the complications of TI came from comparing TI and TM patients from two centers in Lebanon and Italy. The results were remarkable in that some complications were exclusively found in TI patients [16]. A better understanding of the complications came from the OPTIMAL CARE study. This study was a cross-sectional survey of 584 TI patients from six centers throughout the Middle East and Italy. Different complications were correlated with different exposures and treatments [19]. The complications are discussed below and summarized in Table II.

\section{A. Thrombophilia}

TI patients are at a higher risk of thrombosis than TM patients. Out of 2,190 TI patients, 3.9\% experienced a thrombotic event compared to only $0.9 \%$ of $6,670 \mathrm{TM}$ patients [20]. The events were mainly venous. Splenectomized patients were at a higher risk of thrombosis than non-splenectomized patients. Additional risk factors for thrombosis were low hemoglobin concentration $(<9 \mathrm{~g} / \mathrm{dl})$ and transfusion-independence. Studies are still lacking on this subject but there are several proposed mechanisms. RBC remnants express negatively charged phosphatidylserine residues on their membranes which act as procoagulants, initiating thrombosis [21-22]. Activation of platelets, endothelial cells, monocytes, and depletion of

\begin{tabular}{|c|c|}
\hline \multicolumn{2}{|c|}{$\begin{array}{c}\text { TABLE I } \\
\text { MODIFIERS OF THALASSEMIA INTERMEDIA }\end{array}$} \\
\hline Mutation affecting the beta globin is mild & Resulting imbalance between alpha and beta chains is mild \\
\hline Co-inheritance of alpha and beta thalassemia & Imbalance is compensated for by less of the other chain being synthesized \\
\hline $\begin{array}{r}\text { Inheritance of modifiers that increase gamma chain } \\
\text { production }\end{array}$ & $\begin{array}{l}\text { Excess alpha chains will pair with excess gamma chains decreasing the deleterious } \\
\text { effect of the free alpha chains }\end{array}$ \\
\hline Tertiary modifiers & $\begin{array}{l}\text { Genes not related to globin synthesis but that may play a role in the presentation } \\
\text { (iron absorption, bilirubin metabolism, bone metabolism, cardiovascular disease, and } \\
\text { susceptibility to Infection) } \\
\text { Environmental and socioeconomic factors }\end{array}$ \\
\hline
\end{tabular}


anti-thrombotic factors are also incriminated along with the cardiac, endocrine, and hepatic dysfunction [23]. Other risk factors include age [24], previous thromboembolic events, and family history.

These patients are important to identify and treat because sequelae include pulmonary hypertension with ensuing secondary heart failure [25] and silent brain abnormalities $[18,26]$. Recommended therapies include aspirin or other platelet anti-aggregants in the case of thrombocytosis, or anticoagulant agents such as low molecular weight heparin in patients with documented thrombosis or for those undergoing surgery. Blood transfusions might

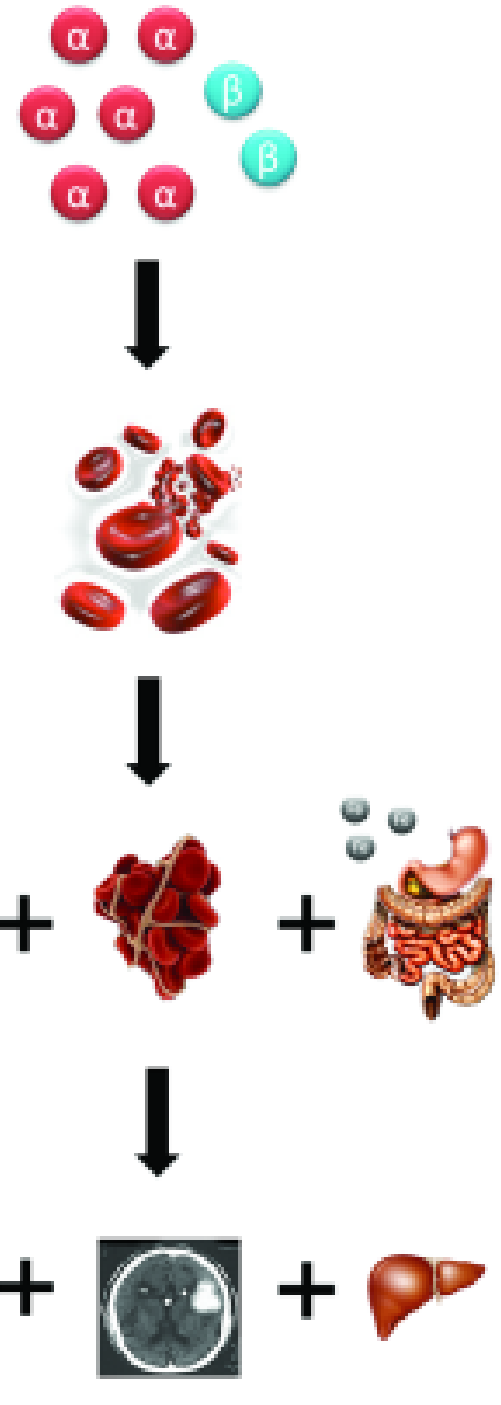

FIGURE 1

Pathophysiology of thalassemia intermedia in a nutshell.

An imbalance in the ratio of alpha to non-alpha (beta) chains leads to cell lysis and ineffective erythropoiesis. This leads to characteristic bony changes, hypercoagulability, and increased gastrointestinal iron absorption. Osteoporosis and fractures, silent brain infarcts, pulmonary hypertension, and iron overload ensue. be considered as they dilute the circulating damaged RBCs. More studies are needed to establish a risk-assessment model that would stratify the patients according to their risks and guide a tailored therapy to this issue.

\section{B. Iron overload}

Iron is controlled by a negative feedback loop. Inflammation and excess plasma iron is a stimulant for the transcription of hepcidin. Hepcidin interacts with ferroportin - the iron exporter - on the basolateral surfaces of hepatocytes and the intestinal epithelium and causes its internalization and degradation [27]. This traps iron inside the cells and makes it less available in the blood stream. In the hepatocytes, macrophages, and other cells of the reticuloendothelial system, it is stored in its ferritin-bound form for later use. In the endothelial cells, intracellular iron is shed with the shedding of the epithelium. Hypoxia, anemia, and a demand for erythropoiesis suppress hepcidin, making more iron available for the bone marrow through increased intestinal absorption and better recycling of catabolic iron from the reticuloendothelial system [28]. Ineffective erythropoiesis increases expression of growth differentiation factor 15 (GDF15) and hypoxia-inducible transcription factors (HIFs) [28] which cause down-regulation of hepcidin. This increases intestinal iron absorption and depletes the macrophages of their iron stores.

TABLE II
COMPLICATIONS OF THALASSEMIA INTERMEDIA
AND THEIR MANAGEMENT


After all the iron saturates the transferrin stores, it is transported as the toxic non-transferrin-bound-iron. The end result is its deposition in the parenchyma of the liver, heart, endocrine organs, and others.

Body iron levels are usually assessed by ferritin values. However, studies have shown that ferritin underestimates the total iron burden in TI [29]. For the same value of liver iron concentration, ferritin values in TI patients were significantly lower than TM patients. A proposed mechanism for this is that iron in transfused patients is preferentially distributed to the reticuloendothelial system, thus ferritin is more readily synthesized and exported [28]. This is in contrast to transfusion-independent TI patients, where low hepcidin depletes the reticuloendothelial system of its iron stores, thus ferritin will be low. Other methods of evaluating body iron stores include determination of liver iron concentration by biopsy or more recently by noninvasive techniques such as R2 MRI.

\section{Splenectomy and cholecystectomy}

The main indications for splenectomy in TI are poor growth and development, increased transfusion demand, hypersplenism, and splenomegaly [30]. However, splenectomy appears to contribute to an increased risk of thrombosis [22, 31]. Splenectomy is now less common than before and is performed later in life [8]. Gallstones are common in TI because of the ineffective erythropoiesis and peripheral hemolysis. That is why the gallbladder should be inspected during splenectomy to avoid further complications.

\section{Extramedullary hematopoiesis}

Extramedullary hematopoiesis (EMH) is when erythropoietic tissue outside marrow spaces in bones increases to compensate for the chronic state of anemia that accompanies TI. This will lead to the formation of erythropoietic masses that primarily affect the spleen, liver, and lymph nodes [8]. These masses can cause local symptoms such as neurological symptoms and spinal cord compressions [32-33]. Splenic enlargement can cause symptoms such as early satiety, left upper quadrant pain, and even raises concerns about splenic rupture [30]. Extramedullary hematopoiesis is routinely managed by radiotherapy, hydroxyurea, or transfusion therapy [32, 34-35].

\section{E. Pulmonary hypertension}

Pulmonary hypertension (PH) is defined as pulmonary artery pressure of $>25 \mathrm{mmHg}$ at rest or $>30 \mathrm{mmHg}$ during exercise [36]. In TI, the prevalence is estimated to be around $59 \%$. This, in turn, contributes to an increased incidence of congestive heart failure [37]. The etiology of PH in TI is multifactorial. PH results from interplay of vasoconstriction, vascular smooth muscle proliferation, and dysfunctional endothelium with resulting thrombosis, all of which contribute to luminal narrowing and right-sided failure. Major risk factors include advancing age and a history of splenectomy [38]. Autopsy studies in thalassemia patients have revealed common histopathological findings that include plexiform and concentric medial hyperplastic pulmonary vascular lesions, and in situ pulmonary artery thrombosis [39-40]. The factors that culminate in these pathologies are most likely the result of the long-term sequelae of splenectomy, red cell membrane pathology, coagulation abnormalities, excess arginase activity, low nitric oxide bioavailability, platelet activation, oxidative stress, iron overload, and chronic hemolysis [41-45]. The correlation of ferritin with PH is still controversial with one study indicating no correlation [46] while another study reporting a strong correlation between an elevated tricuspid regurgitant jet velocity (TRV) and serum ferritin [47]. Hemolysis disables the arginine-nitric oxide pathway by releasing erythrocyte arginase [48] and cell-free hemoglobin [43]. With the consumption of nitric oxide and arginine, endothelial dysfunction ensues, and along with the intravascular hemolysis, this will create a procoagulant state [49]. Iron overload, and the subsequent oxidative stress, can also contribute to increasing the pulmonary vasculature resistance through various mechanisms. They induce pulmonary fibrosis and affect the pump itself through cardiac siderosis [50]. The hypoxemia, along with the chronic anemia, will also exacerbate the vasoconstriction [38].

Currently, there are no guidelines for the treatment of $\mathrm{PH}$ in TI specifically. In one small trial, $\mathrm{PH}$ was absent in patients taking hydroxyurea, suggesting a protective role, but further studies are needed [51]. Two small studies reported improvement in exercise tolerance in response to sildenafil [52-53]. General recommendations for the management of $\mathrm{PH}$ now are adequate treatment of thalassemia, any precipitating factors or associated diseases, in addition to supportive measures [38]. A multidisciplinary approach is needed and a cardiopulmonary specialist should be on board.

\section{F. Leg ulcers, endocrine dysfunction, and hepatitis}

TI patients are also at risk for other complications. Leg ulcers occur more commonly in older patients. Leg ulcers develop in some patients with low hemoglobin and do not develop in others, even though they are maintained at the same amount of fetal hemoglobin, implying that it is multifactorial in origin. The skin might be at a lower oxygen tension due to the anemia, making it fragile and more prone to break with minimal trauma. These also cause impaired healing. These are usually managed by an intense transfusion regimen to elevate the hemoglobin concentration by a minimum of $2 \mathrm{~g} / \mathrm{dl}$. Other possible interventions include elevating the end of the bed so as to keep the lower limbs at a level above the heart. This provides better venous return and increases the perfusion pressure of the affected area [8]. Zinc supplementation [54], pentoxifylline, and hydroxyurea, with or without erythropoietin [55] are also possible options.

While endocrine dysfunction can be quite common in TM, it is quite rare in TI. Patients generally experience late puberty, but their sexual development is normal and their fertility preserved. However, hypothyroidism 


\begin{tabular}{|c|c|c|}
\hline \multicolumn{3}{|c|}{$\begin{array}{c}\text { TABLE III } \\
\text { MANAGEMENT OF THALASSEMIA INTERMEDIA }\end{array}$} \\
\hline \multicolumn{3}{|c|}{ THERAPY } \\
\hline Conventional & Non-conventional & Radical \\
\hline Transfusion therapy & Gene therapy & Stem cell transplant \\
\hline Iron chelation therapy & Fetal $\mathrm{Hb}$ modulation & \\
\hline Splenectomy & & \\
\hline Supportive therapy & & \\
\hline Psychological support & & \\
\hline \multicolumn{3}{|c|}{$\mathrm{Hb}$ : hemoglobin } \\
\hline
\end{tabular}

can be a late occurrence sometimes [8].

Viral hepatitis is much rarer in TI than in TM due to the fact that TI patients are less often transfused. Nevertheless, the risk is not absent and careful monitoring should be undertaken [56]. New complications, such as hepatocellular carcinoma are emerging as patients are living longer.

\section{MANAGEMENT}

\section{A. Iron chelation therapy \pm transfusion therapy}

The management of TI has come a long way this decade with the new oral chelators, gene therapy, and Jak2 inhibitors [Table III]. Transfusion is the only available salvage therapy when severe symptoms of anemia set in, including developmental delay in the pediatric age group. Associated risks include alloimmunisation, which is relatively common in TI, especially if transfusions are instituted after the age of 12 months [57]. Rhesus and Kell phenotyping is recommended prior to transfusion [58], with some physicians advocating a short course of steroids for 3-5 days concomitantly, even though this remains controversial.

The rate of iron loading in TI is variable and changes with transfusional load. Iron loading in non-transfused patients is estimated to be $2-5$ grams per year [59] compared to 7.5-15.1 grams per year for transfused patients [60]. Iron loading should always be assessed by liver iron concentration (LIC), preferably by non-invasive MRI imaging, and iron chelation therapy initiated accordingly. Previously, an LIC of $7 \mathrm{mgFe} / \mathrm{g}$ dry weight was used to initiate therapy; however, a recent study has found that an LIC of $7 \mathrm{mgFe} / \mathrm{g}$ dry weight is associated with vascular complications and an LIC of $6 \mathrm{mgFe} / \mathrm{g}$ dry weight is associated with endocrine comorbidities, meaning that complications would have already set in, and chelation should start before that [61].

The gold standard remains desferrioxamine injections which is given subcutaneously or intravenously for prolonged periods of time and is associated with significant patient discomfort, decreased quality of life, and noncompliance [62-63] despite significant mortality and morbidity reductions [64]. Deferasirox, a once-daily oral iron chelator, has been found to be safe and efficacious in reducing iron burden in TI [65].

A novel oral iron chelator is also under development for clinical use. The molecule is still in phase II clinical trials, but the results seems promising [66]. Extensive preclinical toxicological studies demonstrated a higher no-observable-adverse-effect level (NOAEL) compared to deferasirox.

\section{B. Stem cell transplantation}

Hematopoietic stem-cell transplantation is essentially curative in properly selected candidates. Good candidates with high success rates include pediatric patients who have not developed complications such as viral hepatitis or severe iron overload and who receive HLA-identical related donor stem-cell transplants. The event-free survival for beta-thalassemia patients reported from several groups is $80-90 \%$ with less than $10 \%$ mortality and minimal morbidity, apart from impaired fertility [67-70]. The problem is in the availability of donors. Disease-free survival is lower, and morbidity and mortality are higher with unrelated haploidentical donors [71-73]. Definitive hematopoietic stem cells can be obtained from cord blood. Several studies have assessed the use of cord-blood transplantation for patients with thalassemia [69], and the outcomes of related cord-blood stem cell transplantation for beta-thalassemia are approaching those of conventional bone marrow transplantation with disease-free survival of $90 \%$. A cord-blood bank will also allow unrelated transplants to take place, but data is still scarce [74-76].

The physician, patient, and everybody concerned should be involved in the transplantation decision given the associated morbidity, mortality, and cost of the procedure (Figure 2).

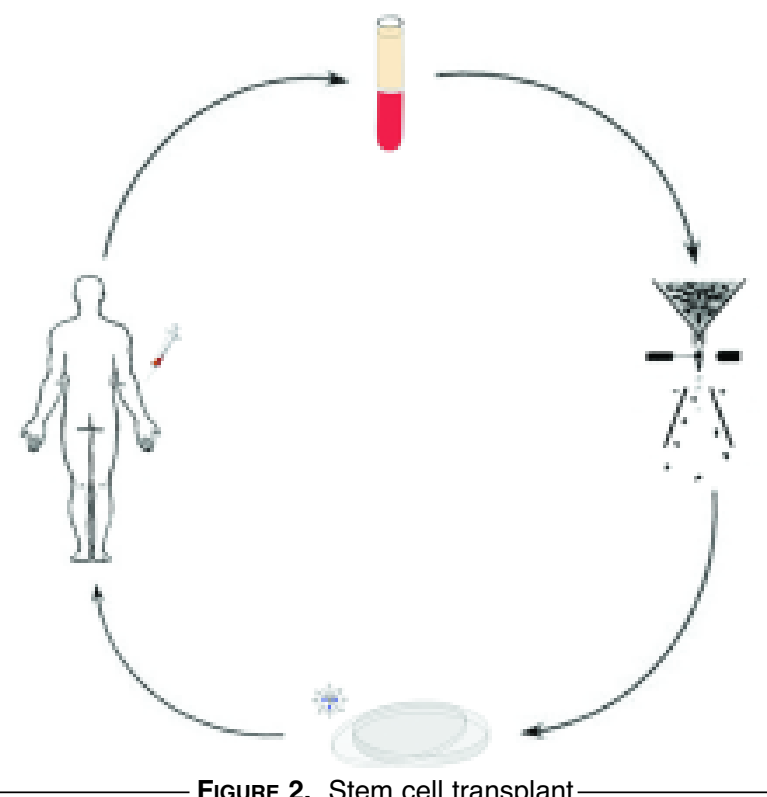

After administering granulocyte-colony stimulating factor for mobilizing stem cells, peripheral blood mononuclear cells are harvested from peripheral blood. They are then purified and selected for $C D 34+$ cells. These cells are then cultured with viral vectors carrying the normal beta-globin gene. The modified stem cells are then engrafted in the patient after non-ablative myelosuppression. 


\section{Gene therapy}

Thalassemia is an ideal disease for gene therapy since its genetic defect only affects the erythroid lineage in the hematopoietic system. The concept is simple, albeit the mechanism is technically demanding. Hematopoietic stem cells are harvested from the patient and infected with a virus carrying the beta-globin gene along with its upstream regulatory elements, and then infused back after myelosuppression. The fact that the patient's own cells are used overcomes the problem of scarcity of donors and associated immunological complications.

A lot of work has been put to develop viral constructs that are able to accommodate all the sequences needed for the expression of the beta-globin gene. "Boundary elements" are now frequently included in the genetic complexes to include proper insertion. Boundary elements are sequences that flank the gene and delimit the activity of the regulatory elements of that gene [77]. Another setback was the associated risk of leukemia with the use of retroviral vectors. Therefore, lentiviral vectors were developed and they have proven successful in mouse models both in TM and TI [78-83]. A clinical trial to test this lentiviral vector has already begun in 2007 on two patients [84-85]. One of the patients needed rescue with non-manipulated cells while the other achieved $10 \%$ engraftment and was able to become transfusion independent. The future of gene therapy probably lies in induced pluripotent stem cells, which are human somatic cells that are reprogrammed to form multipotent stem cells [86-87].

\section{Jak2 inhibitors}

Data showed that in ineffective erythropoiesis, there is an accumulation of proliferating erythroid progenitors, and an increase in the percentage of erythroid cells in the S-phase. The thalassemia cells were associated with the expression of certain cell-cycle regulatory genes such as EpoR, Jak2, cyclin-A, Cdk2, Ki-67 and the antiapoptotic protein Bcl-XL, and differentiated less. In thalassemic mice, a Jak2 inhibitor reversed ineffective erythropoiesis and decreased spleen size with limited effect on anemia. Jak2 inhibitors would be expected to limit or reduce splenomegaly, thus improving anemia and delaying the need for splenectomy. A decrease in ineffective erythropoiesis is also expected to upregulate hepcidin, thus improving the metabolism of total body iron content and decreasing end-organ damage [88-90].

\section{CONCLUSION}

Despite all the advances in premarital screening and genetic counseling, thalassemia remains an important genetic disease. With migratory patterns and intermixing of populations, thalassemia is no longer limited to its places of origin. This decade has witnessed breakthroughs in the treatment of thalassemia and we are now able to provide better medical care that is making thalassemia more of a chronic disease than a fatal one.

\section{REFERENCES}

1. Marengo-Rowe AJ. The thalassemias and related disorders. Proc (Bayl Univ Med Cent) 2007; 20 (1): 27-31.

2. Cooley TB, Witwer ER, Lee P. A series of cases of splenomegaly in children and peculiar changes in bones; report of cases. Am J Dis Child 1927; 34: 347-63.

3. Orkin SH, Nathan DG, Ginsburg D, Look AT: Nathan and Oski's Hematology of Infancy and Childhood, Vol. 1, E.H. Sciences, 2009.

4. Whipple GH, Bradford WL. Mediterranean disease "thalassemia" (erythroblastic anemia of Cooley); associated pigment abnormalities simulating hemochromatosis. J Pediatr 1936; 9: 279-311.

5. Weatherall DJ. Thalassaemia: the long road from the bedside through the laboratory to the community. Transfus Med 2011; 21 (4): 218-23.

6. Weatherall DJ. The thalassemia syndromes. Tex Rep Biol Med 1980; 40: 323-33.

7. Cappellini MD, Musallam KM, Taher AT, Insight onto the pathophysiology and clinical complications of thalassemia intermedia. Hemoglobin 2009; 33 (Suppl 1): S145-S159.

8. Cappellini MD, Musallam KM, Cesaretti C, Taher A: Disorders of Erythropoiesis, Erythrocytes and Iron Metabolism, Genoa, Italy: Carole Beaumont et al., editors, Forum Service Editore, 2009.

9. Galanello R, Cao A. Relationship between genotype and phenotype. Thalassemia intermedia. Ann N Y Acad Sci 1998; 850: 325-33.

10. Weatherall DJ. Thalassaemia: the long road from bedside to genome. Nat Rev Genet 2004; 5 (8): 625-31.

11. Ho PJ, Hall GW, Luo LY, Weatherall DJ, Thein SL. Betathalassemia intermedia: is it possible consistently to predict phenotype from genotype? Br J Haematol 1998; 100: 70-8.

12. Rund D, Oron-Karni V, Filon D, Goldfarb A, Rachmilewitz E, Oppenheim A. Genetic analysis of beta-thalassemia intermedia in Israel: diversity of mechanisms and unpredictability of phenotype. Am J Hematol 1997; 54 (1): 16-22.

13. Phadke SR, Agarwal S. Phenotype score to grade the severity of thalassemia intermedia. Indian $\mathbf{J}$ Pediatr 2003; 70 (6): 477-81.

14. Olivieri NF. The beta-thalassemias. N Engl J Med 1999; 341 (2): 99-109.

15. Camaschella C, Cappellini MD. Thalassemia intermedia. Haematologica 1995; 80 (1): 58-68.

16. Taher A, Isma'eel H, Cappellini MD. Thalassemia intermedia: revisited. Blood Cells Mol Dis 2006; 37 (1): 1220.

17. Ataga KI., Cappellini MD, Rachmilewitz EA. Beta-thalassaemia and sickle cell anaemia as paradigms of hypercoagulability. Br J Haematol 2007; 139 (1): 3-13.

18. Musallam KM, Nasreddine W, Beydoun A et al. Brain positron emission tomography in splenectomized adults with beta-thalassemia intermedia: uncovering yet another covert abnormality. Ann Hematol 2011; 35 (5-6): 530-46.

19. Taher AT, Musallam KM, Karimi M et al. Overview on practices in thalassemia intermedia management aiming for lowering complication rates across a region of endemicity: the OPTIMAL CARE study. Blood 2010; 115 (10): 1886-92.

20. Taher A, Isma'eel G, Mehio G et al. Prevalence of thromboembolic events among 8,860 patients with thalas- 
saemia major and intermedia in the Mediterranean area and Iran. Thromb Haemost 2006; 96 (4): 488-91.

21. Eldor A, Rachmilewitz EA. The hypercoagulable state in thalassemia. Blood 2002; 99 (1): 36-43.

22. Cappellini MD, Robbiolo L, Bottasso BM, Coppola R, Fiorelli G, Mannucci AP. Venous thromboembolism and hypercoagulability in splenectomized patients with thalassaemia intermedia. Br J Haematol 2000; 111 (2): 467-73.

23. Taher AT, Otrock ZK, Uthman I, Cappellini MD. Thalassemia and hypercoagulability. Blood Rev 2008; 22 (5): 283-92.

24. Taher AT, Musallam KM, El-Beshlawy A et al. Age-related complications in treatment-naive patients with thalassaemia intermedia. Br J Haematol 2010; 150 (4): 486-9.

25. El-Beshlawy A, Youssry I, El-Saidi S et al. Pulmonary hypertension in beta-thalassemia major and the role of L-carnitine therapy. Pediatr Hematol Oncol 2008; 25 (8): 734-43.

26. Taher AT, Musallam KM, Nasreddine W, Beydoun A. Covert brain ischaemia in splenectomised adults with thalassemia intermedia: An emerging entity. Thromb Haemost 2010; 104 (3): 652-3.

27. Nemeth E, Tuttle MS, Powelson J et al. Hepcidin regulates cellular iron efflux by binding to ferroportin and inducing its internalization. Science 2004; 306 (5704): 2090-3.

28. Taher A, Hershko C, Cappellini MD. Iron overload in thalassaemia intermedia: reassessment of iron chelation strategies. Br J Haematol 2009; 147 (5): 634-40.

29. Pakbaz Z, Fischer R, Fung E, Nielsen P, Harmatz P, Vichinsky E. Serum ferritin underestimates liver iron concentration in transfusion independent thalassemia patients as compared to regularly transfused thalassemia and sickle cell patients. Pediatr Blood Cancer 2007; 49 (3): 329-32.

30. Taher AT, Musallam KM, Cappellini MD, Weatherall DJ. Optimal management of beta thalassaemia intermedia. Br J Haematol 2011; 152 (5): 512-23.

31. Cappellini MD, Motta I, Musallam KM, Taher AT. Redefining thalassemia as a hypercoagulable state. Ann N Y Acad Sci 2010; 1202: 231-6.

32. Chehal A, Aoun E, Koussa S, Skoury H, Taher A. Hypertransfusion: a successful method of treatment in thalassemia intermedia patients with spinal cord compression secondary to extra-medullary hematopoiesis. Spine (Phila Pa 1976) 2003; 28 (13): E245-E249.

33. Castelli R, Graziadei G, Karimi M, Cappellini MD. Intrathoracic masses due to extramedullary hematopoiesis. Am J Med Sci 2004; 328 (5): 299-303.

34. Saxon BR, Rees D, Olivieri NF. Regression of extramedullary haemopoiesis and augmentation of fetal haemoglobin concentration during hydroxyurea therapy in beta thalassaemia. Br J Haematol 1998; 101 (3): 416-19.

35. Cario H, Wegener M, Debatin KM, Kohne E. Treatment with hydroxyurea in thalassemia intermedia with paravertebral pseudotumors of extramedullary hematopoiesis. Ann Hematol 2002; 81 (8): 478-82.

36. Gladwin MT, Sachdev V, Jison ML et al. Pulmonary hypertension as a risk factor for death in patients with sickle cell disease. N Engl J Med 2004; 350 (9): 886-95.

37. Isma'eel $\mathrm{H}$, Chafic AH, Rassi FE et al. Relation between iron-overload indices, cardiac echo-Doppler, and biochemical markers in thalassemia intermedia. Am J Cardiol 2008; 102 (3): 363-7.

38. Morris CR, Vichinsky EP. Pulmonary hypertension in thalassemia. Ann N Y Acad Sci 2010; 1202: 205-13.
39. Sonakul D, Pacharee P, Thakerngpol K. Pathologic findings in 76 autopsy cases of thalassemia. Birth Defects Orig Artic Ser 1988; 23 (5B): 157-76.

40. Morris CR, Gladwin MT, Kato GJ. Nitric oxide and arginine dysregulation: a novel pathway to pulmonary hypertension in hemolytic disorders. Curr Mol Med 2008; 8 (7): 620-32.

41. Aessopos A, Farmakis D, Deftereos S et al. Thalassemia heart disease: a comparative evaluation of thalassemia major and thalassemia intermedia. Chest 2005; 127 (5): 1523-30.

42. Hahalis G, Alexopoulos D, Kremastinos DT, Zoumbos NC. Heart failure in beta-thalassemia syndromes: a decade of progress. Am J Med 2005; 118 (9): 957-67.

43. Morris CR. Mechanisms of vasculopathy in sickle cell disease and thalassemia. Hematology Am Soc Hematol Educ Program 2008; 177-85.

44. Singer ST, Kuypers FA, Styles L, Vichinsky EP, Foote D, Rosenfeld H. Pulmonary hypertension in thalassemia: association with platelet activation and hypercoagulable state. Am J Hematol 2006; 81 (9): 670-5.

45. Morris CR. Pulmonary hypertension in thalassemia assessed by echocardiography: a report from base-line data of the thalassemia clinical research network Longitudinal Cohort Study. Blood 2009; 114: 796 [abst 2016].

46. Hagar RW, Morris CR, Vichinsky EP. Pulmonary hypertension in thalassaemia major patients with normal left ventricular systolic function. Br J Haematol 2006; 133 (4): 433-5.

47. Mokhtar GM, Adly AA, El Alfy MS, Tawfik LM, Khairy AT. N-terminal natriuretic peptide and ventilationperfusion lung scan in sickle cell disease and thalassemia patients with pulmonary hypertension. Hemoglobin 2010; 34 (1): 78-94.

48. Morris CR. Role of arginase in sickle cell lung disease and hemolytic anemias. Open Nitric Oxide J 2010; 2: 41-54.

49. Setty BN, Betal SG, Zhang J, Stuart MJ. Heme induces endothelial tissue factor expression: potential role in hemostatic activation in patients with hemolytic anemia. J Thromb Haemost 2008; 6 (12): 2202-9.

50. Zakynthinos E, Vassilakopoulos T, Kaltsas P et al. Pulmonary hypertension, interstitial lung fibrosis, and lung iron deposition in thalassaemia major. Thorax 2001; 56 (9): 737-9.

51. Karimi M, Borzouee M, Mehrabani A, Cohan N. Echocardiographic finding in beta-thalassemia intermedia and major: absence of pulmonary hypertension following hydroxyurea treatment in beta-thalassemia intermedia. Eur J Haematol 2009; 82 (3): 213-18.

52. Derchi G, Forni GL, Formisano F et al. Efficacy and safety of sildenafil in the treatment of severe pulmonary hypertension in patients with hemoglobinopathies. Haematologica 2005; 90 (4): 452-8.

53. Littera R, La Nasa G, Derchi G, Cappellini MD, Chang CY, Contu L. Long-term treatment with sildenafil in a thalassemic patient with pulmonary hypertension. Blood 2002; 100 (4): 1516-17.

54. Gupta VL, Choubey BS. RBC survival, zinc deficiency, and efficacy of zinc therapy in sickle cell disease. Birth Defects Orig Artic Ser 1987; 23 (5A): 477-83.

55. al-Momen AK. Recombinant human erythropoietin induced rapid healing of a chronic leg ulcer in a patient with sickle cell disease. Acta Haematol 1991; 86 (1): 46-8. 
56. Mancuso A. Hepatocellular carcinoma in thalassemia: A critical review. World J Hepato 2010; 2 (5): 171-4.

57. Spanos T, Karageorga M, Ladis V, Peristeri J, Hatziliami A, Kattamis C. Red cell alloantibodies in patients with thalassemia. Vox Sang 1990; 58 (1): 50-5.

58. Hmida S, Mojaat N, Maamar M, Bejaoui M, Mediouni M, Boukef K. Red cell alloantibodies in patients with haemoglobinopathies. Nouv Rev Fr Hematol 1994; 36 (5): 363-6.

59. Pippard MJ, Callender ST, Finch CA. Ferrioxamine excretion in iron-loaded man. Blood 1982; 60 (2): 28894.

60. Federation TI. Guidelines for the clinical management of thalassemia. 2004. Available from: http://www.thalassaemia. org/cy/Publications/htm

61. Musallam KM, Cappellini MD, Wood JC et al. Elevated liver iron concentration is a marker of increased morbidity in patients with \{beta\} thalassemia intermedia. Haematologica 2011; 96 (11): 1605-12.

62. Treadwell MJ, Weissman L. Improving adherence with deferoxamine regimens for patients receiving chronic transfusion therapy. Semin Hematol 2001; 38 (1 Suppl 1): 77-84.

63. Cappellini MD. Overcoming the challenge of patient compliance with iron chelation therapy. Semin Hematol 2005; 42 (2 Suppl 1): S19-S21.

64. Cossu P, Toccafondi C, Vardeu F et al. Iron overload and desferrioxamine chelation therapy in beta-thalassemia intermedia. Eur J Pediatr 1981; 137 (3): 267-71.

65. Taher AT, Porter J, Viprakasit V et al. Deferasirox reduces iron overload significantly in nontransfusion-dependent thalassemia: 1-year results from a prospective, randomized, double-blind, placebo-controlled study. Blood 2012; 120 (5): 970-7.

66. Rienhoff HY Jr, Viprakasit V, Tay L et al. A phase 1 doseescalation study: safety, tolerability, and pharmacokinetics of FBS0701, a novel oral iron chelator for the treatment of transfusional iron overload. Haematologica 2011; 96 (4): 521-5.

67. Krishnamurti L, Bunn HF, Williams AM, Tolar J. Hematopoietic cell transplantation for hemoglobinopathies. Curr Probl Pediatr Adolesc Health Care 2008; 38 (1): 6-18.

68. Lucarelli G, Galimberti M, Polchi P et al. Bone marrow transplantation in patients with thalassemia. N Engl J Med 1990; 322 (7): 417-21.

69. Pinto FO, Roberts I. Cord blood stem cell transplantation for haemoglobinopathies. Br J Haematol 2008; 141 (3): 309-24.

70. Smiers FJ, Krishnamurti L, Lucarelli G. Hematopoietic stem cell transplantation for hemoglobinopathies: current practice and emerging trends. Pediatr Clin North Am 2010; 57 (1): 181-205.

71. Dini G, Lanino E, Lamparelli $\mathrm{T}$ et al. Unrelated donor marrow transplantation: initial experience of the Italian bone marrow transplant group (GITMO). Bone Marrow Transplant 1996; 17 (1): 55-62.

72. La Nasa G, Giardini C, Argiolu F et al. Unrelated donor bone marrow transplantation for thalassemia: the effect of extended haplotypes. Blood 2002; 99 (12): 4350-6.

73. Yannaki E, Emery DW, Stamatoyannopoulos G. Gene therapy for beta-thalassaemia: the continuing challenge. Expert Rev Mol Med 2010; 12: e31.

74. Boncimino A, Bertaina A, Locatelli F. Cord blood transplantation in patients with hemoglobinopathies. Transfus Apher Sci 2010; 42 (3): 277-81.

75. Hall JG, Martin PL, Wood S, Kurtzberg J. Unrelated umbilical cord blood transplantation for an infant with beta-thalassemia major. J Pediatr Hematol Oncol 2004; $26(6): 382-5$.

76. Jaing TH, Hung IJ, Yang CP, Chen SH, Sun CF, Chow R. Rapid and complete donor chimerism after unrelated mismatched cord blood transplantation in 5 children with beta-thalassemia major. Biol Blood Marrow Transplant 2005; 11 (5): 349-53.

77. Gaszner M. Felsenfeld G. Insulators: exploiting transcriptional and epigenetic mechanisms. Nat Rev Genet 2006; 7 (9): 703-13.

78. May C, Rivella S, Chadburn A, Sadelain M. Successful treatment of murine beta-thalassemia intermedia by transfer of the human beta-globin gene. Blood 2002; 99 (6): 1902-8.

79. Hacein-Bey-Abina S, Von Kalle C, Schmidt M et al. LMO2-associated clonal $\mathrm{T}$ cell proliferation in two patients after gene therapy for SCID-X1. Science 2003; 302 (5644): 415-19.

80. Hacein-Bey-Abina S, Hauer J, Lim A et al. Efficacy of gene therapy for X-linked severe combined immunodeficiency. N Engl J Med 2010; 363 (4): 355-64.

81. Imren S, Payen E, Westerman KA et al. Permanent and panerythroid correction of murine beta thalassemia by multiple lentiviral integration in hematopoietic stem cells. Proc Natl Acad Sci U S A 2002; 99 (22): 14380-5.

82. May C, Rivella S, Callegari J et al. Therapeutic haemoglobin synthesis in beta-thalassaemic mice expressing lentivirus-encoded human beta-globin. Nature 2000; 406 (6791): 82-6.

83. Persons DA, Hargrove PW, Allay ER, Hanawa H, Nienhuis AW. The degree of phenotypic correction of murine beta-thalassemia intermedia following lentiviralmediated transfer of a human gamma-globin gene is influenced by chromosomal position effects and vector copy number. Blood 2003; 101 (6): 2175-83.

84. Cavazzana-Calvo M, Payen E, Negre O et al. Transfusion independence and HMGA2 activation after gene therapy of human beta-thalassaemia. Nature 2010; 467 (7313): 318-22.

85. Kaiser J. Gene therapy. Beta-thalassemia treatment succeeds, with a caveat. Science 2009; 326 (5959): 1468-9.

86. Takahashi K, Tanabe K, Ohnuki M et al. Induction of pluripotent stem cells from adult human fibroblasts by defined factors. Cell 2007; 131 (5): 861-72.

87. Takahashi K, Okita K, Nakagawa M, Yamanaka S. Induction of pluripotent stem cells from fibroblast cultures. Nat Protoc 2007; 2 (12): 3081-9.

88. Taher A, Mehio G, Isma'eel H, Cappellini MD. Stroke in thalassemia: a dilemma. Am J Hematol 2008; 83 (4): 343.

89. Rivella S. Ineffective erythropoiesis and thalassemias. Curr Opin Hematol 2009; 16 (3): 187-94.

90. Libani IV, Guy EC, Melchiori L et al. Decreased differentiation of erythroid cells exacerbates ineffective erythropoiesis in beta-thalassemia. Blood 2008; 112 (3): 875-85. 